\title{
Transformation to irregular structure of an upland conifer forest
}

\author{
by E.R. Wilson ${ }^{1}$, H. Whitney McIver ${ }^{1}$ and D.C. Malcolm ${ }^{1,2}$
}

The Glentress Trial was established by M.L. Anderson in 1952 as a demonstration of transformation to irregular structure of an upland conifer forest in southern Scotland. The trial area (117 ha) is one of the longest continuously-studied forest research areas in Britain. The dominant tree species are Sitka spruce, European larch, Scots pine and Douglas-fir. The most important silvicultural system is group selection, with group size varying from 0.1 to 0.2 ha. Groups are restocked by planting or natural regeneration. Interim results point to the development of an irregular forest structure, although the transformation will not be complete until 2033. The trial demonstrates the value of continuous cover forests in meeting multiple forest management objectives, and is a resource of increasing importance for silviculture education and long-term research.

Key words: transformation, irregular structure, uneven-aged management, Sitka spruce, Douglas-fir, long-term silviculture research

\section{Introduction}

Clear-felling is the predominant silvicultural system in northern Europe and Scandinavia. This practice has been especially important in Britain where extensive afforestation over the past seventy years has created a forest resource that is largely composed of even-aged plantations (Savill $e t$ al. 1997). Now, however, there is widespread concern that clearfelling does not satisfy the wider social, ecological and conservation functions of many forest ecosystems. This has led to renewed interest in silvicultural systems that maintain a continuous forest cover over the site and harvesting regimes that emulate small-scale natural disturbances to create multi-aged stands of irregular structure (Malcolm 1997). Europeans call this "nature-oriented" or "close-to-nature" forestry, with the desired stand structures most often achieved through singletree or group selection systems. A number of professional forestry organisations, including Pro Silva (Europe) and the Continuous Cover Forestry Group (Britain), actively promote wider application of alternative silviculture systems to clear-felling.

The management of irregular structure forests in Britain has not been encouraged in the past, either through grant aid or tax incentives. Most research has concentrated on plantation forestry (Wood 1974) and there are few working examples available for study of alternative silvicultural systems (Whitney McIver 1992, Hart 1995). A notable exception can be found at Glentress Forest, in southern Scotland, where for over 45 years researchers at the School of Forestry, University of Edinburgh,

\footnotetext{
${ }^{1}$ School of Forestry, Institute of Ecology and Resource Management, University of Edinburgh, Darwin Building, Kings' Buildings, Mayfield Road, Edinburgh, Scotland EH9 3JU.

${ }^{2}$ Author to whom correspondence should be addressed.
}

Le Glentress Trial a ete mis en place par M.L. Anderson en 1952 a titre de demonstration de la transformation vers une structure irreguliere d'une foret de coniferes de haute altitude dans le sud de l'Ecosse. Le site de l'essai (117 ha) constitue l'un des sites de recherche ininterrompue les plus vieux en Grande-Bretagne. Les principales especes d'arbres sont l'epinette de Sitka, le meleze europeen, le pin sylvestre et le sapin Douglas. Le plus important regime sylvicole est la coupe progressive par bouquet, chaque bouquet variant de 0.1 a 0.2 hectare. Les trouees sont regarnies par plantation ou laissees a la regeneration naturelle. Les resultats interimaires tendent vers un developpement d'une structure irreguliere, meme si la transformation ne sera pas completee avant 2033. Cet essai demontre l'importance des forets a couverture continue pour l'atteinte des objectifs multiples d'amenagement forestier, et est une ressource importante pour l'education en sylviculture et la recherche a long terme.

Mots-cles: transformation, structure irreguliere, amenagement inequienne, epinette de Sitka, sapin Douglas, recherche sylvicole a long terme in partnership with the British Forestry Commission, have been transforming ${ }^{3}$ an upland conifer forest from even-aged plantations to an irregular structure using the group selection system. Although only partially complete, this trial serves an important role in demonstrating the value and practicality of alternative silvicultural systems. The objectives of this paper are, therefore, to detail the history of the Glentress Trial, outline some emerging results and discuss the importance of long-term silviculture research, with reference to irregular structure forests in Britain.

\section{History of Glentress Trial}

The Glentress Trial was established in 1952 by M. L. Anderson (1895-1961), Professor of Forestry (1951-1961) at the Department (now School) of Forestry, University of Edinburgh. He promoted the idea that mixed-species, irregular-structure forests could provide the ecological conditions necessary for sustained yield, with protection of regenerating seedlings and saplings from wind and other disturbance factors (Anderson 1951, Malcolm 1992). Anderson postulated that this approach was suitable at high elevations where irregularity would inevitably develop in even-aged plantations through endemic windthrow, disease and site variability. In the early $1950 \mathrm{~s}$ he instituted several operational trials, including the Glentress

\footnotetext{
${ }^{3}$ Transformation is the process whereby an even-aged forest structure is transformed to a mixed, uneven-aged or irregular structure, through an alternative silvicultural system to clear-felling. This process has been referred to as a "conversion," but as this term has been used to designate a change in land use (e.g., from forest to agriculture or other non-forest land uses) we promote the term "transformation."
} 


\begin{tabular}{ll}
\hline Table 1. Site conditions of the Glentress Trial Area \\
\hline Total area: & $117 \mathrm{ha}$ \\
Altitude range: & $240-560 \mathrm{~m}$ \\
Annual precipitation: & $1000-1500 \mathrm{~mm}$ \\
General aspect: & Southwest \\
& - exposure to wind accentuated by funnelling \\
up valley \\
Windthrow hazard class: & II - IV (on scale of I - V) \\
Soils: & - derived from Ordovician sediments \\
& - podsolized peaty thin iron pan soils on upper \\
& slopes \\
& - well-drained acid brunisols on lower slopes \\
& - heavy till in lower areas \\
Ground vegetation: & grass-heath type on upper slopes, with \\
& Deschampsia flexuosa/Vaccinium myrtillus \\
& - grass-herb type with ferns (Holcus/ \\
& Dryopteris) with Deschampsia caespitosa in \\
small mid-slope flushes
\end{tabular}

Trial, to gain experience in the management of irregularstructure stands (Hart 1995). The model for these demonstrations was the spruce-fir-beech protection forests managed under the single-tree selection system in the Swiss Jura (Knuchel 1953, Anderson 1960); the distinction being that the species used in Scotland would be mainly exotic species of North American origin.

The trial is located at Glentress Forest, a 4400 ha state forest $3 \mathrm{~km}$ east of Peebles ( $50 \mathrm{~km}$ south of Edinburgh). The trial area (117 ha) was mostly planted between 1921 and 1946, at an altitude range from 240 to $560 \mathrm{~m}$ (Table 1). The main species employed were: Douglas-fir (Pseudotsuga menziesii (Mirb.) Franco) at lower elevations (240-320 m); Japanese larch (Larix kaempferi (Lamb.) Carr.) and European larch (Larix decidua Mill.) at mid-elevations (320-400 m); and, Scots pine (Pinus sylvestris L.) and Corsican pine (Pinus nigra var. maritima (Ait.) Melville) on upper slopes (400-560 m). These upper sites were partially replaced with Sitka spruce (Picea sitchensis (Bong.) Carr.) and Norway spruce (Picea abies (L.) Karst.) in the 1940s. Western hemlock (Tsuga heterophylla (Raf.) Sarg.), grand fir (Abies grandis Lindl.) and several hardwood species were also introduced at different dates and in small numbers.

\section{Group Selection System}

To achieve the desired forest structure, Anderson proposed a "rotation" of 60 years for the production of crop trees of up to $65 \mathrm{~cm}$ dbh. The trial area was divided into six blocks of approximately 20 ha (Fig. 1), with the goal of regenerating approximately 2 ha in each block on a six-year cutting cycle. The original silvicultural system was based on single-tree or small-group selection and gaps were regenerated by planting clusters of seedlings (one or two species) at a spacing of $0.9 \times 0.9 \mathrm{~m}$ (Anderson 1951). However, this approach soon proved impractical due to higher costs of extraction and establishment, the complexity of operations and planning, and canopy gaps being too small for sustained growth of the shade intolerant and mid-tolerant species employed at Glentress. Consequently, from the mid-1960s group size increased to between 0.1 and $0.2 \mathrm{ha}$. Groups of $0.1 \mathrm{ha}$ are favoured on exposed upper slopes to ensure that regenerating seedlings receive protection from the surrounding stand; larger groups are possible on sheltered lower slopes. Areas are restocked by plant- ing $(2 \times 2 \mathrm{~m}$ spacing $)$ or natural regeneration. Approximately 12 groups are selected in each block and harvesting proceeds on an annual basis in a sequence from one block to another. The regenerated areas thus create a mosaic of size classes which provides good wildlife habitat, enhanced recreation and visual amenity values, and silvicultural benefits of shelter and appropriate shade for young trees (Fig. 2). The evolution of this silvicultural system is described in detail by Blyth and Malcolm (1988), Malcolm (1992) and Whitney McIver et al. (1992).

\section{Results}

The original plan forecast a transformation of the forest over 60 years (i.e., by 2013). However, the schedule has been modified due to planting failures, problems with deer-browse, uncertainty about natural regeneration and several breaks in the harvesting plan. It is now likely that transformation will be complete by 2033 (Blyth 1993).

Periodic inventories have provided data for stem size distributions, growth rates and yield. The most recent inventory was completed in 1991, using permanently marked transects, in a stratified random design. These transects will be re-sampled at approximately 10-year intervals. Sitka spruce, European larch, Scots pine and Douglas-fir are the dominant species, although there is large variation between blocks in terms of both species composition and growing stock (Table 2). There is a higher proportion of Sitka spruce than was originally proposed and a correspondingly lower proportion of shade tolerant conifers and beech (Fagus sylvatica L.). Browsing pressure by sheep and deer in the early years of the transformation is primarily responsible for this distribution.

Despite modifications to the transformation schedule, the initial plantations (up to 35 years old in 1952) are gradually developing an irregular structure (Fig. 3a). The ideal stand structure is characterised by an inverse exponential size-frequency distribution. On this basis, there are currently insufficient stems in the smallest size class $(<7 \mathrm{~cm} \mathrm{dbh})$. This is attributed to browse damage and a lack of tending in regenerating groups throughout the 1980s. In addition, there appears to be an over-abundance of stems in the middle size classes $(17-42 \mathrm{~cm}$ $\mathrm{dbh}$ ) with rather small numbers of larger stems above $42 \mathrm{~cm}$ dbh (Figure 3b). This is partially a result of thinning in many mid-rotation stands being neglected due to technical and financial constraints. Appropriate rates of regeneration and thinning are clearly important to the development of a balanced irregular forest structure.

\section{Discussion: Operational Considerations and Challenges}

Transformations should be initiated when the majority of the stands are in mid-rotation (Whitney McIver 1992, Yorke 1998). This requires sacrifice in volume production in the shortto medium-term but keeps the age gap between newly-regenerated groups and the older forest areas as small as possible. As mid-rotation stands are being "set back" through early felling, the rate of current increment is kept high, although the overall standing volume develops slowly until later in the transformation period. This situation is now occurring at Glentress as the remaining component of the original forest reaches maturity. However, the transformation has not been undertaken without addressing a number of technical and silvicultural challenges. 


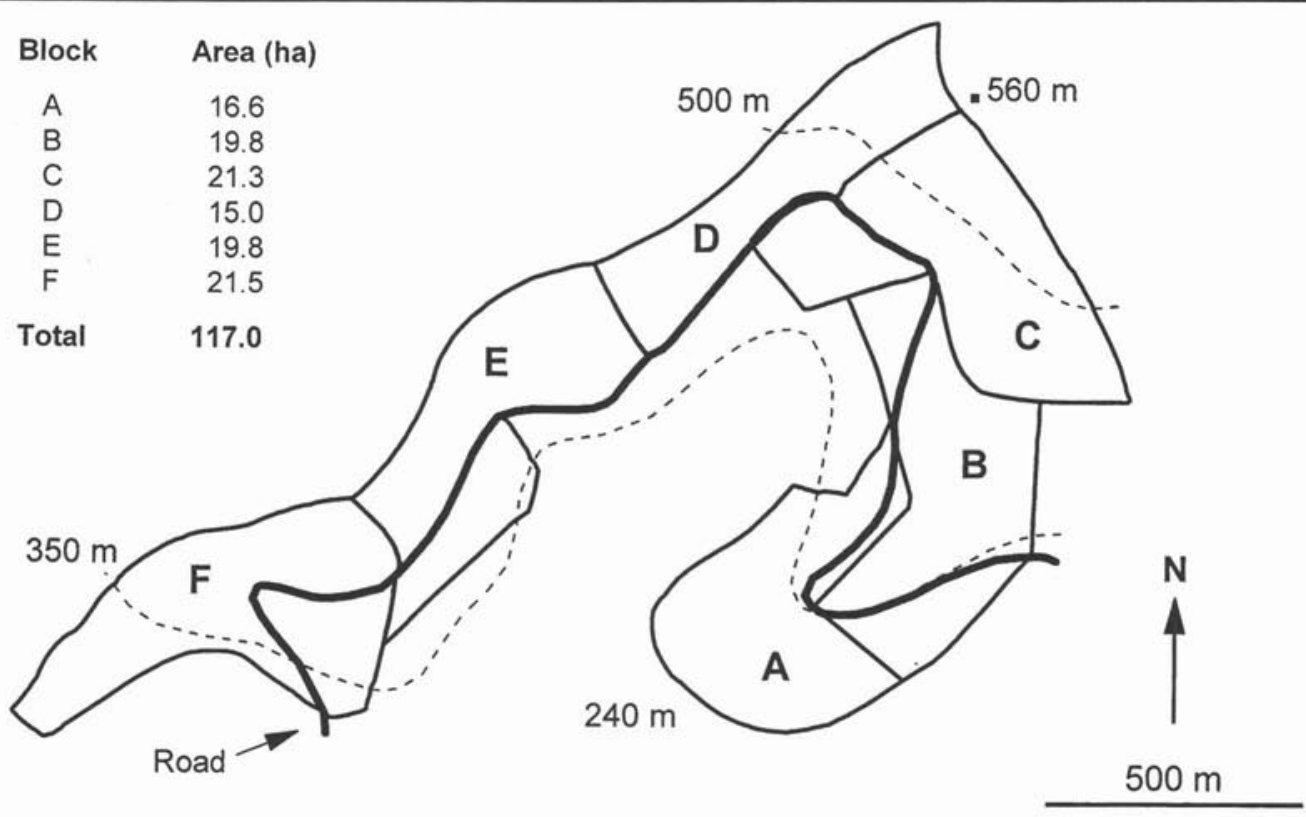

Fig. 1. Map of the Glentress Trial Area.

\section{Harvesting}

A new approach to harvesting is necessary now that the transformation is $60 \%$ complete. This must accommodate the extraction of crop trees, thinned stems and a variety of species. This mix of products is an inherent feature of irregular structure forests. Harvest volume is gradually increasing as the forest matures, with crop trees ranging from 40 to $65 \mathrm{~cm} \mathrm{dbh}$, depending on species and site conditions. However, as indicated in the basal area distribution (Fig. 3b), a thinning schedule needs to be developed to ensure that future crops are released from competition. The primary technical barrier is the use of forwarders (Blyth 1993). These machines are effective in clear-fell operations elsewhere in the district but are ill-suited for operating on steep slopes or in closed forest conditions. Horses or small skidders would be preferable because of their greater manoeuvrability (Shrimpton 1990), but a more likely solution to this problem is the development of a permanent network of forwarder tracks (60-100 m apart) (Blyth 1993). This should improve safety, access and also minimise damage in regenerating groups.

\section{Regeneration}

Initially, groups were too small for sustained growth of seedlings and much browse damage was caused by sheep and deer. Thus, with time and adoption of larger group sizes, an increasing proportion of Sitka spruce and relatively shade intolerant species came to dominate the trial area. Although hardwoods would be desirable, browse has restricted establishment and growth of most species except sycamore (Acer pseudoplatanus L.). Since the 1991 inventory, there has been a renewed effort to promote, protect and release seedlings in regenerating groups in order to restore a balanced size-frequency distribution. Current plans are to increase the proportion of Douglas-fir below $300 \mathrm{~m}$, increase the variety and proportion of hardwoods and reduce reliance on Sitka spruce at higher ele- vations (Table 2). In addition, efforts are being made to promote natural regeneration wherever the desired species composition can be achieved.

\section{Economics}

Costs and revenues have not been recorded accurately enough to make definitive statements, but it is estimated that establishment costs may be up to $50 \%$ higher and harvesting costs 10-20\% higher than standard rates (Shrimpton 1990). Costs should take into consideration the value and benefits of permanent forest cover for amenity, recreation and nature conservation but no satisfactory accounting system has been developed thus far. There remains a need for collection and analysis of harvesting and transformation costs to make objective comparisons between contrasting silvicultural systems.

\section{Administration}

The trial originally operated on the basis of a "gentleman's agreement" between the University and the Forestry Commission. This worked well for 40 years but was replaced by a formal contract in 1991. Under this agreement, the Forestry Commission carries out operations on a three-year work plan developed in consultation with staff at the School of Forestry. However, changes in the structure of the Forestry Commission and the expansion of afforestation in southeast Scotland over the last 50 years have meant that the trial area is only a small component of the Forest District. The trial, therefore, has made some demands on local managers who are generally focussed on larger operations elsewhere in the district. Frequent personnel transfers have increased staff flexibility and exposure to alternative silviculture systems. Unfortunately, these changes have also involved a lack of continuity in management and limited development of transferable skills and experience in the transformation process. 

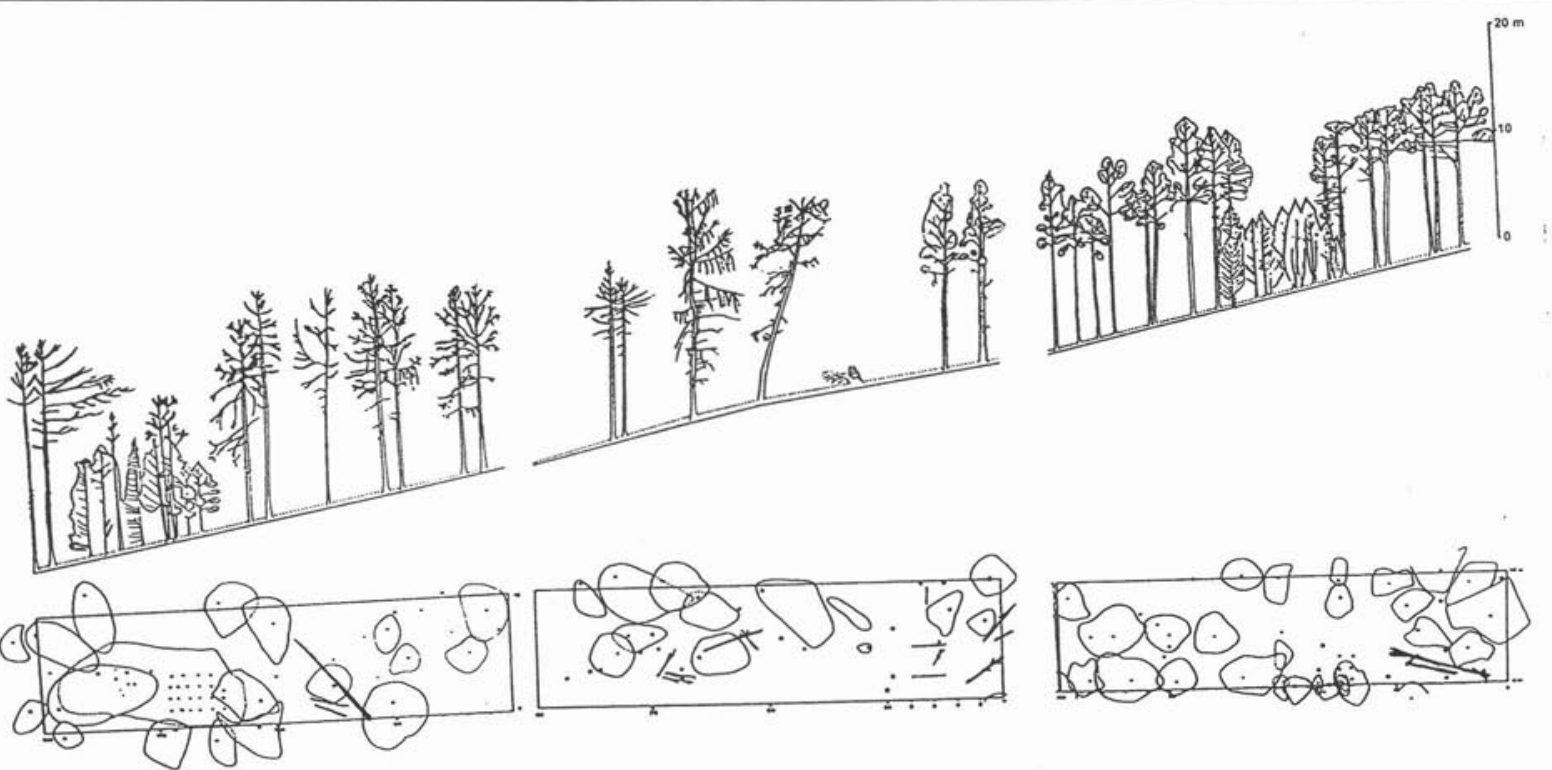

Fig. 2. Stand profile and plan for a transect at Glentress Trial Area (1993). Note the relatively uniform structure of the original stand, with occasional gaps due to thinning or natural disturbance. One newly created and two older groups are shown in the profile. An increasingly complex mosaic of groups of different size and age is slowly transforming the original plantations to an irregular structure. Total length of transect is $120 \mathrm{~m}$, width of plot is $10 \mathrm{~m}$. This illustration is one of a series for the Glentress Trial by H. Whitney McIver.

Table 2. Current and proposed species composition (\% abundance) and current standing volume $\left(\mathrm{m}^{3} / \mathrm{ha}\right)$ for each species group and block (A-F) in the Glentress Trial area. The proposed species composition above and below $325 \mathrm{~m}$ highlights plans to limit the dominance of Sitka spruce and increase the proportion of hardwoods throughout the trial area

\begin{tabular}{|c|c|c|c|c|c|c|c|c|c|c|}
\hline \multirow[b]{2}{*}{ Block } & \multicolumn{2}{|c|}{ Spruce } & \multicolumn{2}{|c|}{ Pine } & \multicolumn{2}{|c|}{ Larch } & \multicolumn{2}{|c|}{ Other conifers $^{1}$} & \multicolumn{2}{|c|}{ Broadleaves $^{2}$} \\
\hline & $\%$ & vol & $\%$ & vol & $\%$ & vol & $\%$ & vol & $\%$ & Vol \\
\hline \multicolumn{11}{|c|}{ Current status: } \\
\hline A & 33 & 18 & 11 & 59 & 17 & 92 & 38 & 79 & 1 & 0.2 \\
\hline B & 38 & 45 & 27 & 83 & 25 & 90 & 7 & 17 & 3 & 3 \\
\hline C & 74 & 216 & 6 & 6 & 18 & 37 & 1 & 0.5 & 1 & 0.4 \\
\hline D & 72 & 234 & 5 & 7 & 22 & 57 & 1 & 0.3 & - & 0.1 \\
\hline $\mathrm{E}$ & 71 & 177 & 11 & 12 & 11 & 29 & 6 & 19 & 1 & 1 \\
\hline $\mathrm{F}$ & 67 & 179 & 5 & 19 & 26 & 61 & - & 1 & 2 & 0.5 \\
\hline Average & 65 & 145 & 10 & 31 & 18 & 61 & 5 & 20 & 2 & 0.9 \\
\hline \multicolumn{11}{|l|}{ Proposed: } \\
\hline$<325 \mathrm{~m}$ & 37 & & 3 & & 15 & & 35 & & 10 & \\
\hline$>325 \mathrm{~m}$ & 60 & & 15 & & 15 & & 5 & & 5 & \\
\hline
\end{tabular}

${ }_{1}^{1}$ mainly Douglas-fir (especially Block A), but also includes grand fir, western hemlock and western red cedar (Thuja plicata D. Don).

${ }^{2}$ species include: sycamore, beech, sessile oak (Quercus petraea (Mattuschka) Lieblein), Norway maple (Acer platanoides L.), rowan (Sorbus aucuparia L.), alder (Alnus glutinosa (L.) Gaertn.) and birch (Betula spp.).

\section{Research and Education}

The Glentress Trial has proved to be an excellent education resource, providing a field site for over 35 B.Sc. (Honours) dissertations and five doctoral theses. Topics have included silviculture, tree biology, soils, wildlife, recreation and economics. The trial also serves as a demonstration site for forestry practitioners and has hosted groups of private landowners, policy makers, managers and silviculturists. However, longterm funding has been difficult to obtain and much of the research at Glentress has relied on volunteers and in-kind support from other agencies. The opportunity to promote technology transfer and extension has also been limited by lack of funding.

\section{Social Values}

In recent years emphasis on timber production in Britain has been relaxed in response to societal pressure for forests that meet landscape, conservation and biodiversity objectives (Malcolm 1997, Hodge et al. 1998). The recent designation of Glentress Forest as a Woodland Park acknowledges the importance of the transformation in meeting integrated resource management objectives and also affords greater protection for the site, at a time when many state forests have been sold to the private sector.

\section{Conclusions: From Research to Application}

The Glentress Trial is the only example of transformation in upland Britain that has continued for over 40 years. Throughout this time, the transformation has been conducted in the face of both changing technology and management strategies. However, this has demonstrated the inherent flexibility of alternative silvicultural systems and the ability of foresters and 


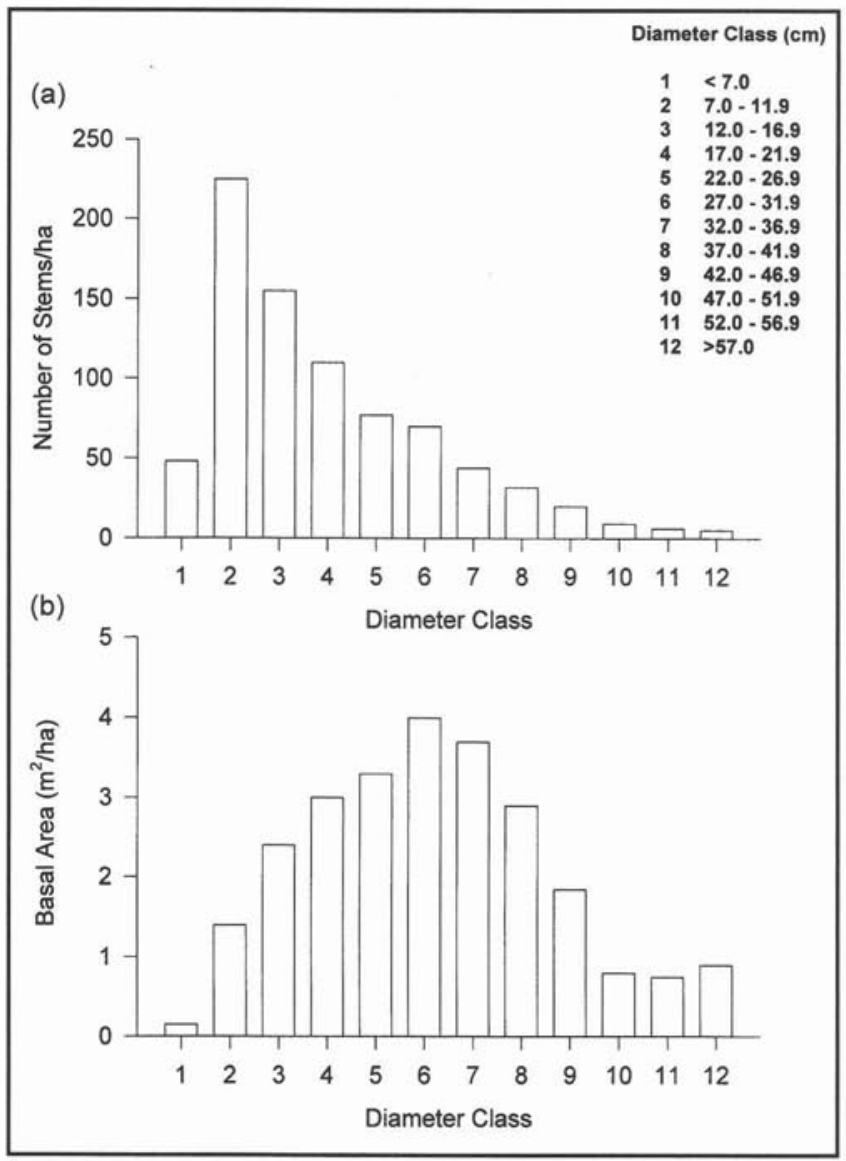

Fig. 3. (a) Number of stems (No./ha) and (b) basal area $\left(\mathrm{m}^{2} / \mathrm{ha}\right)$ by diameter class at the Glentress Trial area (1991). Diameter classes are based on diameter at breast height in $5 \mathrm{~cm}$ classes.

researchers to absorb changes, accrue knowledge and adapt to problems. Despite administrative and technical challenges, the trial is now playing a central role in deliberations about the expansion of irregular structure forestry in Scotland. A decision to undertake a transformation in any forest area depends on site conditions, the need for multi-purpose management, the importance of continuous forest cover and landscape aesthetics, and the long-term commitment of both the landowner and staff.

In terms of long-term research, the trial has also yielded some lessons, including the need for:

\section{Sustained Leadership and Communication}

The success of the trial demonstrates the role of key individuals who have the foresight to initiate long-term studies, and also those who follow and maintain a commitment to the initial research objectives. Leaders can sustain interest, communicate project objectives and lobby for funds in times of financial constraint. It is fortunate that silviculturists at the University of Edinburgh, starting with M.L. Anderson, have actively supported the Glentress transformation. In addition, communicating results of the project is vital to securing long-term support. This must be done through peer review publications, technical reports, technology transfer and public education to reach all stakeholders and decision-makers. Leadership and communication are especially important at times when only intermediate or inconclusive results are available.

\section{Adaptive Research}

Glentress demonstrates the value of an adaptive research approach in long-term studies where overall objectives are more important than the details of implementation. Such an approach allows for rapid response to lessons learned from initial silvicultural treatments, developments in harvesting technology, and changes in forest management and administration. In addition, an adaptive strategy can accommodate new and emerging research priorities, and facilitate interdisciplinary partnerships and research. Adaptability, teamwork and sustained research at the "cutting edge" of forest science are central to project recognition.

\section{Long-term Planning}

The current popularity of irregular structure forests suggests that a long-term view must be taken, not only in the maintenance of silviculture research trials, but also in the research questions that we ask when such trials are initiated. Funding agencies, academic institutions, forestry administrations and industry must cooperate in the establishment and maintenance of long-term studies that satisfy short term, applied or "mission-oriented" research goals and those of a more "speculative" nature. In this way we have the best opportunity to sustain critical levels of knowledge and management expertise, thus avoiding the age-old problem in forestry of always "re-inventing the wheel" in response to changes in social values and technology.

\section{Acknowledgements}

The continuing support of the Forestry Commission is gratefully acknowledged. Partial funding for research and inventory work has been provided by the Scottish Forestry Trust. The authors wish to thank colleagues and students at the School of Forestry, University of Edinburgh for their various contributions over many years of the transformation process. Thanks to Kristjan Vitols and Mara Kerry, Faculty of Forestry, University of Toronto, for review and helpful comment on draft versions of this paper.

\section{References}

Anderson, M.L. 1951. Spaced group-planting and irregularity of stand structure. Empire Forestry Review 30: 328-341.

Anderson, M. L. 1960. Norway spruce-silver fir-beech mixed selection forest: Is it possible to reproduce this in Scotland? Scottish Forestry 14: 87-93.

Blyth, J. F. 1993. Towards irregular structure in forestry: the Glentress Trial, 1993. Sylva 56: 22-28.

Blyth, J. F., and D. C. Malcolm. 1988. The development of a transformation to irregular forest: 35 years' experience at the Glentress Trial Area. OFI Occasional Paper No. 37. pp. 33-41. Oxford Forestry Institute, Oxford.

Hart, C. 1995. Alternative silvicultural systems to clear cutting in Britain: a review. Forestry Commission Bulletin 115. Her Majesty's Stationery Office, London. 93 p.

Hodge, S. J., G. Patterson and R. McIntosh. 1998. The approach of the British Forestry Commission to the conservation of forest biodiversity. Scottish Forestry 52: 30-36.

Knuchel, H. 1953. Planning and Control in the Managed Forest. Oliver and Boyd, Edinburgh. 360 p.

Malcolm, D. C. 1992. The development of a transformation from evenaged plantations to an irregularly-structured forest. Report to the Scottish Forestry Trust. School of Forestry, Institute of Ecology and Resource 
Management, University of Edinburgh, Edinburgh. 22 p.

Malcolm, D. C. 1997. The silviculture of conifers in Great Britain. Forestry 70(4): 293-307.

Savill, P., J. Evans, D. Auclair and J. Falck. 1997. Plantation silviculture in Europe. Oxford University Press, Oxford. 297 p.

Shrimpton, N. H. 1990. An economic assessment of uneven-aged forestry based on modelling of forest operations. $\mathrm{PhD}$ Thesis. University of Edinburgh. 186 p.

Whitney McIver, H. 1992. Forests of irregular structure. Institute of Chartered Foresters, Edinburgh. 57 p. (plus 2 appendices; 400 refs. 180 p.)
Whitney McIver, H., J. F. Blyth and D. C. Malcolm. 1992. The application of group selection working in an upland forest in south Scotland (Glentress Forest). Scottish Forestry 46: 202-211.

Wood, R. F. 1974. Fifty years of forestry research. Forestry Commission Bulletin 50. Her Majesty's Stationery Office, London. $134 \mathrm{p}$.

Yorke, M. 1998. Continuous cover silviculture: an alternative to clear felling. Practical guide. 52 p. (Copies available from author: M. Yorke FICFor, Tyddyn Bach, Llanegryn, Tywyn, Gwynedd, Wales LL36 9UF). 